$i$ the morning without any medical assistance whatever, and this circumstance reflects very little credit on that wretched parsimonious system, which, apparently intended to consign poor lying-in women to chance-women, too, who are afterwards acknowledged to be paupers, rclieved out of the parish funds, and yet most unjustly denied the services of the medical officer in the time of their utmost need, because it involves an expenditure of ten shillings! I would rather be the man to attend these cases for nothing than him who would refuse all just remuneration. Supposing Catherine Duffy, or any other of the five cases I have lately attended without an order, had been the wife of a poor-law guardian instead of a poor, destitute Irishman, she would undoubtedly have had some consideration bestowed upon her, and not been allowed to struggle through the pains and penalties accompanying childbirth without prompt and able assistance. What difference is there, I would ask, between the Queen in labour and Catherine Duffy? None whatever. I repcat, Sir, the system which would deny medical aid to poor lying-in women cannot be too severely deprecated. It is not only un-English, but grossly barbarous.

Now, with regard to the refusal of the fee. Article 182 says-" In cases in which any medical officer, either for the workhouse or a district, shall be called on, by order of a person legally qualified to make such order, to attend any woman $i n$, or immediately after, childbirth," \&c. This settles the question at once, and on these words I found my claim. I was called into the house of Catheriue Duffy by her husband on the afternoon of the same day on which she was confined; I supplied her with medicine, and visited her again; besides this, I prescribed for and supplied her husband with medicine. In fact, I saw the woman fairly over the puerperal state, and discharged my duty conscientiously, and in strict compliance with the plain provision in Article 182.

In your letter there is some ingenuity; at all events, there is a lamentable oversight in your quotation (it may lave been dusk, as it soon is in November), I mean, in omitting the words which I trust I have rendered so legible as not to be over. looked this time, and confining yourself with all stress (the gas no doubt had just been lit) to the following, nor were you called in afterwards under circumstances of diffculty or danger. Now, I would humbly ask, how do you know this? The board certainly cannot tell the circumstances-the relieving officer cannot tell-nor can you yourself tell. In fact, the circumstances of the case, in a medical point of view, are only known to myself; and, therefore, I beg to submit to your good judgment that the words $I$ have underlined above, are neither more nor less than a gratuitous assertion. I would remind you, in all humility, that Article 182 awards ten shillings for all ordinary cases, but for extraordinary cases, in. volving "circumstances of difficulty or danger," the medical officer is entitled to twenty shillings; and it is right such a distinction should be made. I mean no offence by these remarks, nor do I harbour any ill-will. I but follow out the law, and I desire nothing but what is reasonable and just.

In conclusion, $\mathrm{Sir}, \mathrm{I}$ am of opinion that a medicil officer, who, in order to discharge faithfully a most responsible duty, is compolled to walk about the streets at all hours of the day and night; to sit for hours together in garrets and in cellars, amidst filth and destitution, amidst squalor and wretchedness, unseen it may be, but no less useful on that account; such a man, I say, ought not to be deprived by any chicanery, however subtle, of a paltry sum of ten shillings, especially when the law has provided for its honourable payment.

Under these circumstances, I protest, respectfully yet firmly, against the decision of the board, and I ask, again, for a more rational and considerate management of these important cases. I may just observe, that Catherine Duffy, Mary Taylor, and Sarah Bird, have all received parochial relief immediately subsequent to confinement, and that $I$ was called out of bed to attend upon the two latter.

I have the honour to be, dear Sir, your obedient servant, Halifax, Nov. 19, 1819. Frederick SMITH GARUICK.

P.S.- To this letter I have as yet received no written reply, but I understand the fees have all been allowed, with th
exception of that for Catherine Duffy.

\section{ON THE EMPLOYMENT OF THE FORCEPS IN MIDWIFERY.}

To the Editor of The Lancet.

SrR,-“" Oh that mine adversary had written a book?" exclaimed the most patient of mankind. My waspish adversary has written his book; he has brought the affair to a tangible shape, and he must endure the consequence.

The Lancet of January $13 \mathrm{th}, 1849$, contained an article from me, " On Employing Instruments in Midwifery" in which I stated, that of 1484 labours, three only were delivered by the forceps, being rather less than one in 491 . And this I stated in furtherance of the late Dr. D. D. Davis's reasonings on this important subject, as contained in the following passage from his "Elements of Operative Midwifery":- "Upon the whole, therefore, I am much inclined to the opinion, that it cannot be absolutely necessary to have recourse to the use of the forceps or the lever more frequently than once in 300 , or at most in 250 cases, in order to ensure for puerperal women the greatest possible advantages attainable from the employment of these obstetric powers."

Eight months passed away, when, in The LavceT of September 22nd, appeared the first letter of Mr. C. Stewart, Sen., containing a graceless and illiberal attack upon me and my practice, winding up with these remarkable words:- " I cannot coincide with the opinion of Dr. Davis, that 'it cannot be absolutely necessary to have recourse to the use of the forceps more frequently than once in 300 , or, at most, 250 cases,' and unhesitatingly give it as my conviction, that such a limited use of them is far from 'ensuring for puerperal women the greatest possible advantages attainable from these obstetric powers.' Inceed, I would not readily affirm that they may not be em. ployed with advantage in as great an average as one in fifty."

To this bumptions letter I gave a "laconic" reply in THE LINCET of November 24, simply calling the serious attention of Mr. Stewart to some midwifery statistics of Dr. F. $H$. Ramsbotham, by which it appeared, that of 26,776 women, only thirty-four were delivered by the forceps, being less than one in every 787 cases!

The Lincet of Saturday last contains a second letter from Mr. Stewart, wherein he says, - "The object of his paper was, to show that the instrument, as recommended by almost all teachers and writers on the obstetric art, is rarely had recourse to, and always as a desperate resource, and that therefore its use is much more limited than safety dictates, or reason demands." Here, then, we are at issue. My object in publishing a statistical record of mid wifery cases occurring in my private practice, was just the reverse. I believe the forceps are very often had recourse to sashly, and unnecessarily, in order to save time and tronble, and more particularly by practitioners who pride themselves up on their mechanical abilities.

Mr. Stewart next finds fault with what he calls "a holf table of statisties." Why a "half table"? Why travel out of the record, when the question between us only refers to forceps cases?

I now desire to call Mr. Stewart's attention to Dr. Simpson's able letter, "On Operative Midwifery," in the same LAxceT, wherein he gives a table showing the proportion of deliveries by forceps in different obstetric institutions-thus:

$$
\begin{aligned}
& \text { Lever-London ................ } 1 \text { in } 518 \\
& \text { Simpson-Edinburgh .......... } 1 \text { in } 472 \\
& \text { Collins-Dublin ................. } 1 \text { in } 617
\end{aligned}
$$

Will Mr. Stewart, after this, continue to maintain that the forceps may be employed with advantage in as great an average as one in fifty cases? Did he use the forceps eighty times in attending the 4000 accouchements spoken of by him? If so, how forcibly the words he quoted from the Mantuan bard, "Qua ipse miserrima vidi, et quorum pars magna fui" apply to himself, and the words which immediately follow, "Quis talia fando temperet a lacrymis ?" to the numerous readers of The Larcetr.-I am, Sir, yours obediently,

Margate, Dec. 19, 1849. JoShUA W ADDINGToN, F.R.C.S.E.

\section{MR. SAX'TON OF MARKET DRAYTON, IN REPLY TO THE LETTER OF DR. WOOD.*}

Market Drayton, December 1849

Srr,-Before again asking Mr. Wakley to give his opinion on the question of medical etiquette at Market Drayton, it is necessary to point out to him the misrepresentations you have made; and of this my intention, I thick it proper to give you intimation.

In the first place you state that I made use of this expression to you-"They ought to have known better than to have sent for you, and you ought to have known better than to have gone to see him." This is totally incorrect, a ruse to draw attention from my real charge against you-viz., of omitting 
to send for me in consultation, and this omission unqualified by any extenuating circumstances-of sending me a note, a verbal message, directing your prescription to me or my surgery, or giving me the earliest intimation of what was going on-any one of which would have been an excuse I could have received; and even now, if it be possible you can be under any misapprehension of my charge against you, and can say that you had no intention of slighting me, can give any reason for the omission, I could yet pass all over. The absurdity of my upbraiding any medical man for rendering assistance in case of emergency is a sufficient refutation of such a silly charge; but if any refutation is required by any person, I shall refer them to my first letter, where they will observe, I spoke of your going when sent for as a matter of course; in your own words "Had yon not visited the patient under such circumstances you ought to have been scouted out of the profession." But having given your attendance, it then became your duty to send for me in consultation; and your omitting to do so is the breach of professional etiquette of which I complain; and more especially now, as, by your own admission, there was nothing urgent in the case, forbidding five minutes' delay, and that you knew I was within five minutes' call. I contend, also, it was your duty to have sent for me in justice to your patient. How conld you tell that he was not under the influence of medicine which $I$ had given him ? You make use of an expression, " the wife followed my directions, and immediately after service called on Mr. Saxton with the prescription:" thereby insinuating that she followed your directions in bringing the prescription to my surgery. This insinuation is not true; by your own admission you told her to get the medicine "prepared somewhere," and she distinctly told me you had given her no directions whatever to me; and for the fact of the prescription finding its way to my surgery there are no thanks due to you. She came to me after service, and told me of your visit, that you had ordered this medicine, handing the prescription; and stating that her husband was so much better she thought he did not require it, and asked my opinion on that point, which I refused to give; as I always decline further interference in a case when I discover there has been clandestine consultation with other me. dical men. And this is the abuse, I presume, of which she complains; it is only from extraneous information I learned that the medicine had not been prepared somewhere and taken.

Your next assertion that you called on me within three hours may be correct, but my impression is, the time was much later than six o'clock; however, can any one reasonably state, that calling on me three hours after the occurrence of a fainting fit could avail the patient anything, or be giving me the earliest information of what was going on, when the residence of the patient was closely adjoining both mine and yours? I am, however, willing to give you credit for calling, as far as it goes, and it may be some excuse, bat I am only informed by your letter, that your call was not subsequent to your finding $I$ had declined further interference in the case. I must also express my surprise, that you should say it would have been useless sending the prescription to Mr. Saxton sooner, as Mr. Saxton has neitler apprentice nor assistant, when it is notorious to all, not wilfully ignorant, that my wife's father and brother, both experienced dispensers of medicine, are residing near, and are constantly dispensing medicine for me : had I been 500 miles off there would have been no delay; but how vain the excuse, when you knew I was within five minutes' call.

Another untrue assertion you make is, that I before charged you, rudely and untruly, with influencing a patient not to employ me. I never did so. I related to you that a friend of mine informed me such was the case, and the remarks that I made to her at the time; and on your assuring me there was not a word of truth in it, I took no further notice of it. In conclusion, I beg to thank you for your kind advice; no doubt your intention was benevolent. I cannot do less than return the compliment at my earliest opportunity, perhaps with the publication of the above.-I am, Sir, your obedient servant,

To Dr. Wood.

W. W. SAXTON.

\section{REMUNERATION FOR MEDICAL SERVICES. To the Elditor of The Lancet.}

SIR,-I apprehend that there are few practitioners in medicine and surgery who will not agree with you that the subject of tees, legally obtainable, is one of the utmost importance to the profession, and ought to be made a prominent matter in any forthcoming measure of medical reform.
The custom of charging for medicines is fast becoming obsolete, and deservedly so; indeed, the fact that medical practice, during the past few years, has completely changed, is well known to all ; formerly, in every slight ailment the medical adviser was consulted; now, it is only when the medicine-chest and "suggestive" skill of the druggist have been exhausted, that we are called in; therefore it is that our remuneration ought to be, nay, must be, more liberal. The public are well aware that a sixpenny powder is equally efficacious with an eighteenpenny draught.

I am of opinion that in average country practice, five shillings from the upper classes; three-and-sixpence from the intermediate; and two-and-sixpence from the lower (each inclusive of medicines) would be a fair remunerative legal fee, with a proportionate mileage for out-town visits.

Where, from superior ability, a more wealthy neighbourhood, or a firmer position, larger fees could be obtained, by all means be it so; but those I have quoted, or some similar scale, should at all events be rendered legal. We should not then find, as I believe is now almost universally the fact, that in a practice of $£ 600$ per annum, $£ 100$ would be annually lost in bad debts. Nor would this be without its advantages to our patients. Instead of wearisome journeyings from morning to night, evenings at ledgers, and Januarys occupied in writing bills in order to obtain a precarious livelihood, medical practitioners, as men of science, would have time to devote to studies, and thus enable their brains to cope more successfully with disease, tempora mutantur, et nos mutamur in illis.

Dec. 1849 .

I am, Sir, your obedient servant,

\section{THE ASSURANCE OFFICES AND THE MEDICAL PROFESSION.}

To the Editor of Tha Lancet.

SIR,-Please to publish the enclosed correspondence as soon as possible. Every shot fired at the insurance offices still holding out, should be made known, in order to encourage the timid, decide the wavering, and proclaim to all that the battle proceeds gloriously, and there can now be no doubt of the result.-Your obedient servant,

Albert-terrace, Notting-hill, Dec. 18, 1849. Charles Clark.

(COPY.)

Albert-terrace, Notting.hill, Dec. $15,1849$.

SIR,-I have received a printed letter from you, containing twenty-three queries respecting the health, habits, \&c., of $\mathbf{M r}$. J. W. K-, with a view to his life being assured at your office, but no fee being enclosed, I consider that office must possess a vast deal of assurance which expects me to answer them all for nothing. Ask a lawyer for the same amount of private and confidential information respecting his client for nothing, and mark his reply. If the lawyer, then, sells legal knowledge, why not the doctor medical knowledge, which costs him hundreds of pounds, and many long years of hard study to acquire. I am aware that the argument employed by those offices who refuse our legitimate demand is, that it is the duty of the person wishing to be assured to supply the requisite information to satisfy the office of his or her fitness for insurance, in other words, to prove their case, and to pay for it, if necessary: perhaps this may be so, but as the insurance companies are the parties directly seeking the information from the medical man, manifestly for their own advantage; and as it is of the highest importance to them that it should be accurate; I apprehend they are the proper parties at least to disburse the remuneration, let it come, originally, from whatever source it may.

A reference to THE LANCET of Dec. 25th, 1847, if you think proper to take the trouble for nothing, will show you that $I$ was one of the first to advance in the contest, now triumphantly carried on by the medical profession, against such of the insurance offices as are still foolish enough to withhold the recognition of its just rights. Yon will there see the arguments I adduced, and the course I pursued towards the Eagle Office, on a similar occasion to the present; and as I do not happen to be one of those sneaking cowards who, whilst contending, publicly, for a just principle, will yet privately infringe it to suit their own interest, I am resolved to pursue the same course upon this and every other occasion that opportunity offers, and never sheathe my steel, though it is but a pen, "that mighty instrument of little men" whilst a single office remains in the field, as the champion of injustice and the foe to our legitimate demands.

Until, therefore, you are just, I will not say generous enough. 